\title{
SUNDA WIWITAN ON PARAHYANG LAND
}

\author{
Abdurrahman Misno Bambang Pawiro \\ Al Hidayah College of Islamic Studies, Bogor
}

\begin{abstract}
The arrival of the great religions of the world to Indonesia did not eliminate existing local beliefs/religions of its people. The followers of the local beliefs remained strong in the midst of the spread of the great religions. Although those religions did not eliminate the local beliefs, they in fact had a significant influence on them. Sunda Wiwitan is one of the local beliefs that until today is still parcticed by the Baduy Community in Kanekes Village, Leuwidamar Sub-district, Lebak District of Banten Province. The Baduy people to this day have not embraced any major religions of the world. They are still consistent with the Sunda Wiwitan, believed to be the old legacy of their Sunda ancestors that become their karuhun. The current Sunda Wiwitan belief has been heavily influenced by Hinduism and Islam. Hindu influence gave rise to the concept of gods in their belief, while the influence of Islam gave rise to the terms Allah as God, Adam Tunggal, Adam and Eve, the Shahada (Profession) of Prophet Muhammad, Circumcision, Shahada in marriages. Even mantras recited by the puun also derived a lot of terms from Islam.
\end{abstract}

Keywords: Sunda Wiwitan, Local Belief, Baduy, Parahyang, Banten.

\section{INTRODUCTION}

Indonesia is a multi-cultural country with 1,128 ethnic groups (BPS, 2014). Each of these ethnic groups has different religion and local belief in passed down from their ancestors. The local beliefs came from human consciousness of the "power" outside of himself (Dhavamony, 1995: 51). It is believed to be the truth, so that it continues to be carried out and passed on to the next generation. The arrival of the world's great religions such as Hinduism, Buddhism, Islam and Christianity did not eliminate the local beliefs.

The Baduy are one of the ethnic groups in Indonesia who have local belief that comes from the legacy of their ancestors. They inhabit Kanekes Village, Leuwidamar Sub-district, Lebak District of Banten Province. Their life, up to now, has been still consistent with the local belief of Sunda Wiwitan. As a society that closes itself from all forms of modernization, they live in harmony with nature, take food from it and worship it (Djoewisno, 1988).

The Sunda Wiwitan, the Baduy's traditional belief, etymologically derives from 
two words "Sunda" and "Wiwitan". The term Sunda has a lot of meanings. In geography, there are terms such as Little Sunda, Great Sunda, Sundaland, Sunda Sea, or Soenda Zee and Circum-Sunda Mountain System). All the terms refer to the outlying islands, the continental shelf, continental plate range, a range of mountains and the sea area around the island of Sumatra, Java, Kalimantan, Sulawesi, Bali, Nusa Tenggara, and Maluku (Bemmelen, 1949).

The term Sunda according to the historical record has been around since the Kingdom of Tarumanegara, as shown in stone inscriptions found at Kampung Pasir Muara (Cibungbulang) on the edge of a rice field approximately 1 mile from the Telapak Gajah Inscription left behind by Purnawarman. This inscription is a relic of Suryawarman containing script 4 lines of writing. It reads (according to Bosch): "Ini sabdakalanda juru pangambai kawihaji panyca pasagi marsandeca barpulihkan haji sunda" which means "this sign of speech of Rakeyan the Pangambat expert in 458 Saka year that local governance was restored to the King of Sunda" (Lubis, 2003: 70). The pre-Tarumanagara period, known as the "ancient Sunda", included the regions: Indonesia, Malay Peninsula, Indo China, Southern India, Madagascar and parts of East Africa. The name ancient Sunda was later changed to "Sundalarang" (the Great Sunda) then became "Dwipantara" and after that was changed again to "Nusantara".

The term Sunda was used to name a great Kingdom in West Java, namely the Sunda Kingdom which was known as Pajajaran (Lubis, 2003: 70). During this period, the term Sunda was used in the guidelines and life of the State. So the term "Sunda" in Sunda Wiwitan which was used by the Sunda Kingdom (Pajajaran) means ethics of daily behavior that should be implemented.

Furthermore the term wiwitan means the first, origin, principle, and essence (Ekadjati, 2009: 62). This term refers to the origins of everything, especially of human spirit that comes from God and will return to Him. Hence the term Sunda Wiwitan means belief which is based on the legacy of ancestors since the beginning of time, particularly during the Kingdom of Sunda and Tarumanegara. Of course it was also rooted in the belief in previous period, i.e. during pre-historic time.

Sunda Wiwitan is based on beliefs of Batara Tunggal (One Batara) that is God Almighty who creates and rules the universe. The Single Batara later sent other batara who became the ancestors of all people in the world (Sam, 1996). Batara Cikal as the oldest descendant became the ancestors of the Baduy whom then believed to derive the highest spiritual figure as the puun in this community. The whole commands of the puun have to be carried out because it is the pillar of Sunda Wiwitan. 
Some argue that the Baduy's religion is Hinduism or Buddhism; this statement is not true. The influence of Hinduism exists only in some parts, namely regarding the beliefs of the existence of the gods and goddesses in the belief of Sunda Wiwitan. However, the Baduy position the gods under the power of the Batara so that they are only recognized and never worshipped. It can be proved that until now none of the statues or sculptures is found and worshipped in the Baduy area. Instead, we can find menhir stones, lumping stones, and sasaka on the holy site of the Baduy.

The greatest influence came from the religion of Islam which has penetrated into the belief of Sunda Wiwitan. They know the term Allah, Prophet Adam, Prophet Muhammad, Shahada, circumcision and so on. The influence of Islam on the belief of Sunda Wiwitan began with peace treaty between Sultan Hasanudin and the Baduy community (Garna, 1987: 30). One of the results of that agreement was the establishment of Cicakal Girang Village located on the traditional land of the Baduy, designated specifically to those whose religion was Islam. This village was also a residence for the village priest in charge of teaching shahada to Baduy community members who are getting married (Kurnia, 2010: 84).

Interview with Jaro Sami from Cibeo and other Baduy figures revealed that their current belief is Selam Sunda Wiwitan. The change from Sunda Wiwitan into Selam Sunda Wiwitan is a very interesting evolution of belief for discussion. This paper will examine the Sunda Wiwitan belief observed by the community of Baduy since the beginning of its existence until the influence of Islam on it.

\section{THE HISTORY OF SUNDA WIWITAN}

To trace the origin of the belief of Sunda Wiwitan is not easy. Various influences from the different religions and beliefs caused Sunda wiwitan to have some religious beliefs and rituals similar to religions outside it. However, if we review it carefully, we can reveal how Sunda Wiwitan became what it is today.

Referring to the origins of the Baduy which have many versions, such as locals in charge of keeping the kabuyutan (Kurnia, 2010), from Pajajaran, Banten Girang, and Pangawinan Tribe (Garna, 1987; Jatisunda, 1984; Ekadjati, 2009) so Sunda Wiwitan can be traced from the origins of the tribes. If all opinions concerning the origin of the Baduy combined, then they are not derived from one lineage, but rather from several different groups and the descendants of Prabu Pucuk Umum, Dalem Legono, of Sumedang, descendants of Prabu Siliwangi from Bogor as well as locals in charge of keeping the kabuyutan 
or mandala as a sacred place for this belief (Djoewisno, 1987). Although they descended from different tribes, they have the same belief that is Sunda Wiwitan which is a common belief in the early formation of this ethnic group.

Based on the origins of the Baduy community, their religion might also come from the same time even though the places might be different. This belief was also practiced by the Sundanese particularly under the reign of Pakuan Pajajaran (Sunda Kingdom) with King Siliwangi as its King. One of the references that serves as guidelines for this belief is the manuscript of Siksakanda $\mathrm{Ng}$ Karesian containing pillars of belief and ethics in the everyday life of the Sundanese (Elis, 2008: 61-62). At that time, in fact, the term "Sunda Wiwitan" did not exist yet, so the belief that they had inherited was belief in the forces outside of human that flourished at the time.

Of course Sunda Wiwitan during Kingdom of Sunda (Pajajaran) cannot be separated from the previous belief during the Kingdom of Tarumanegara. As we know it, the religion that developed during the Kingdom of Tarumanegara was Hinduism, Buddhism, and Sunda Wiwitan (Lubis, 2003: 53). Vishnu Hinduism became the official State religion embraced by the nobility. Meanwhile the commoners generally still observed the old local belief that is Sunda Wiwitan. This belief by those from abroad is comparable to animism and dynamism because one of its pillars is belief in the power of the deceased ancestors.

When traced further, Sunda Wiwitan was an ancient belief that has existed since the tribes that inhabited the Indonesian Archipelago were formed. Even older than that, it is the legacy of the megalithic age people who were convinced of the existence of the power on certain objects, animals, and belief in the spirit of a dead person can be protective of their descendants who are still alive (Suhendar, 1985).

Based on the above discussion, the history of Sunda Wiwitan began with a local belief that appeared simultaneously with the early tribes in Indonesia since the megalithic age. The core of this belief is a belief in the existence of forces on objects, animals and spirits of people who have died. At the time of the Tarumanagara Kingdom, this local belief interacted with the adherents of Hinduism so to some extent has been influenced by Hinduism (Jacobs, 2012: 18). During the Sunda Kingdom, this belief was strengthened by a policy of Prabu Siliwangi who supported its development. Next, after Islam came to the land of Sunda, Sunda Wiwitan derived a lot of beliefs from the Islamic religion, whether intentionally or unintentionally (C.M.Pleyte, 2006: 34). Sunda Wiwitan interaction with Muslims has made the belief in part contain Islamic rituals. For example, during a wedding ceremony, they should read the 
shahada of Muhammad as the Messenger of Allah, and circumcision should also be carried out in accordance with the guidance of Islam. Moreover, when they are asked about their religion they will answer our religion is Selam Sunda Wiwitan (interview with Jaro Sami [head of Village] of Cibeo Baduy Dalam).

\section{THE SUNDA WIWITAN TEACHINGS: BATARA, NYI POHACI, AND “GURIANGS”}

The Sunda Wiwitan believes the existence of Batara Tunggal (One Batara) as God Almighty. He is the creator of the universe, all the power submits to him. The concept of the Batara Tunggal has several designations adapted to its functions, such as Batara Jagat (Lord of nature), Batara Seda Niskala (the Unseen), Nu Kawasa (the Powerful) and Sang Hyang Keresa (the Almighty) or Nu Ngersakeun. Batara Tunggal as God dwells in Buana Luhur (upper world) or Buana Nyungcung as the site of the world's most high (sacred) in the belief of Sunda Wiwitan. Batara Tunggal in Sunda Wiwitan in addition to being God, is also man who is believed to come down to Earth to send other Bataras who became the ancestors of the puun, the highest spiritual figure of the Baduy (Jacobs, 2012: 18; Garna, 1987: 60).

The belief that the puun are descendants of a Batara Tunggal grants him legitimacy to determine all matters concerning the belief of Sunda Wiwitan including what to do and what not to do. Interview with Jaro Alim of the Cikeusik Baduy Dalam revealed that the main tasks of the puun are "ngukus nyapu, nyara muja, ngareksakeun Sasaka Pusaka Nagara telung puluh telu, sawidak lima, panca salawe nagara, ngabertapakeun buana, nyekel musti alam, kudu direksakeun" (Steaming and sweeping, setting the puja, maintaining the Sasaka Pusaka Nagara, thirty-three, sixty-five senses twenty-five countries, determining the world, holding the jewels of nature, and should be implemented). These tasks have been inherited from their ancestors, never changed until now, and still exercised by the puun in three villages of Baduy Dalam (Garna, 1987: 66).

In addition to Batara Tunggal, Sunda Wiwitan also believes in the existence of divinities that protect them from various types of evil and disaster. The main deity is a very respected and affects almost all Baduy religious rituals is known Dewi Sri or Shanghyang Sri or also called Nyi Pohaci. She was the goddess who is believed to be incarnated into the rice plant on Earth (Iskandar, 2011: 46). This belief causes the Baduy community to have great respect for rice, since the start of planting, weeding, harvesting and placing it in the leuit (rice barn). Some other deities are also believed to control some other plants such as the goddess Dangdeur (cassava). 
Besides, Sunda Wiwitan also believes in the "Guriang" i.e. the spirits of the ancestors who have passed away. These spirits have a desire to go back to the natural world, a visit to the community, protect their descendants as well as provide a advice on the tradition of wiwitan. The Baduy community also believes that the spirit of a dead parent is always present at certain times incarnated as Wangatua (parent's spirit) to guard the village. Guriang and Wangatua according to their belief reside in Sasaka Domas, a sacred place for the Baduy community (Pleyte, 2006).

In addition to these beliefs, the Baduy community with their Sunda Wiwitan also believes the existence of a variety of power that exists on certain things, certain animals and certain places. They believe that rocks, trees, valleys, mountains and rivers are controlled by unseen creatures, so when one walks past, they should read mantras of protection from disturbance of the creatures. In addition to reading the spell, the offerings are also used for such evil creatures so as not to disturb them.

\section{RELIGIOUS RITUALS OF SUNDA WIWITAN}

The belief in Batara Tunggal, the goddess of rice (Nyi Pohaci) and the Guriangs is manifested in the forms of religious rituals on Sunda Wiwitan in the Baduy community. They performed the rituals as a worship that should be implemented, otherwise, disaster and wrath of their ancestors will befall them. Ritual and celebration as one of the forms of culture is the manifestation of the religion and beliefs of a society (Koentjaraningrat, 2002: 220).

Results of interview with Jaro Alim of Cikeusik Baduy Dalam revealed that religious rituals performed by the followers of Sunda Wiwitan are as follows:

First: Ngukus, i.e. making smoke which done is by burning aromatic substances such as frankincense, eaglewood, madat or sap. In the tradition of the kukus ritual, it is seen as opening a relationship with the unseen world. The fragrant smoke soaring into the sky gives a typical atmosphere expected to reach the upper world and pull its inhabitants, like the strains of low chants of "bul kukus ngukup ka manggung" (smoke flies to feel the upper world). The aromatic substances burned depends on the goals to be achieved, according to the Baduy, each aromatic substance has "occult power".

Second: Ngawalu, linguistically the term is derived from the word Kawalu or "walu" meaning bali - or go back. Then kawalu is kabali or "back". The ceremony is to mark the return of rice "back" into the barn (leuit) after a long time wandering in "weweg sampeg pageuh" the home of her husband (land of the rice field). The Kawalu ceremony takes place three times a year that 
includes Kawalu Tembey (initial) held on March $17^{\text {th }}$ day of Kasa $\left(10^{\text {th }}\right.$ month according to the system of the Kanekes calendar), Kawalu tengah on $18^{\text {th }}$ day of Karo ( $11^{\text {th }}$ month in the system of the Kanekes calendar), and Kawalu tutug (final) held every March $17^{\text {th }}$ of Katiga ( $12^{\text {th }}$ month in the system of the Kanekes calendar). Tangtu Cikartawana in particular only carries out Kawalu Tembey and Kawalu Tutug.

Third: Muja, that is to worship Sasaka Pusaka Buana or Sasaka Pada Ageung by the Puun Cikeusik, at Sasaka Parahiyang or Sasaka Cibeo by Puun by Cibeo. The performance of worship is done by Puun Cikeusik or Puun Cibeo and several people of Baris Kolot on behalf of the Baduy people. Muja at Sasaka Domas lasts all day from morning to afternoon every $7^{\text {th }}$ day of Kalima month, according to the Baduy calendar, while muja at Pada Ageung is held on $16^{\text {th }}$, $17^{\text {th }}$ and $18^{\text {th }}$ day of Kalima month. Before heading off to Worship, the "trusted" Puun Cikeusik and Baris Kolot cleanse their body using white clean cloth. They go to the place of worship fasting, keeping the ground clean (spitting on the ground not allowed, the urinating and bowel movements shall be accommodated with a large bamboo called "lodong") remaining silent. At the end of the Muja process, before coming down, they take some 'white' soil and komala grass to "give blessings" at Tangtu Cikeusik. The Baduy people also fast and break the fast with the 'luluy' (Sundanese: buras) made by parawari. Puun Cikeusik then distributes the white soil and komala grass to residents (who ask for blessings) and in return the residents give back something (money, a knife, perfume or whatever they can give).

Fourth: the Ngalaksa, the ritual of making laksa (food made from rice flour) to be distributed to all members of the Baduy community. This religious ritual is carried out in several stages, and the activities carried out should be done on a regular basis in the orderly process of religious ceremonies in Kanekes. The ritual begins with the making of laksa which is carried out at the end of the third month of Kanekes calendar and lasts for 7 days. The laksa making begins at Kapuunan and continued at the entire village of Panamping. Laksa is made especially from rice of the serang rice field at kapuunan and tuladan rice field at Panamping. Therefore Ngalaksa is sacred because the main ingredient (rice flour) is taken from seven clumps of rice grown in serang rice field of pupuhunan huma (Tangtu area) and tuladan rice field (Panamping area). Pupuhunan is the center of all rice fields or the field where best substances of the Earth can be found. At pupuhunan the Earth power seeps into the rice grain so the laksa becomes aci bumi as the core of the power of the state. Ngalaksa is the ultimate of all muja ceremonies, therefore those tasked with making the laksa should be fasting from start of the making to the completion. 
Fifth: Seba, celebration to present the harvest to the Government. This Festival is held every year and involves the entire community are Baduy. This ritual consists of the granting of the crop harvest to the Head of Lebak District and Banten Governor. This activity is carried out in the months after the harvest in the rice fields. According to Jaro Dainah, seba is a form of hospitality between the community of Baduy and the Government. It serves as an opportunity to socialize with and get close to the Government. The peak of the Seba held in 2013 was centered in the Lebak District Hall and of Banten Gubernatorial Hall. The ritual of Seba begins with the departure of people from Baduy Dalam to the home of Jaro Dainah as Jaro pamarentah. They stay there because the next morning they have to go to Lebak District Office. At 04:50 they departed to the District Office on foot. I was walking with them down the Ciboleger highway towards the Lebak District Hall.

The ritual of bathing together allows them to stay away for a while from the highway. They turn right towards the Cikoreal River to perform ritual baths. This Ritual is intended to clean up the body, especially for those who first join the seba Bathing is perform by a dipping in the river together, followed by a full breakfast brought with them earlier from Kaduketug. After finishing their breakfast, they usually light "cigarettes" which have been cast with spell by the puun.

The next trip is done by walking down the Leuwidamar highway to the Lebak District Hall. Meanwhile the Baduy Luar people used trucks to head there. The Seba in the forms of banana, palm sugar and various other agricultural produce, was transported by truck. This is one way the Baduy Luar people can help in the process of Seba ritual; they become a helper for those of Baduy Dalam who walk on the foot with their seba. The Ritual bath was performed by the people of Baduy Luar on the river behind the Office of the Governor of Banten, i.e. Cibanten River. Together they take turns cleaning the body, especially for those who joined the Seba for the first time. For those who have joined before only washed their face or clean the body.

In addition to the religious rituals, there are still many other rituals held by the followers of Sunda Wiwitan. The dominant one is the veneration of Nyi Pohaci as the goddess of rice, from planting, tending, harvesting to storing in the leuit, there are always special rituals.

\section{SUNDA WIWITAN SURVIVING AMID CHANGING TIMES: MELT OR DESTROYED?}

Sunda Wiwitan community's interactions with Muslims have brought significant influence. The influence can be seen from the faiths to everyday 
rituals. For example, there is only one Batara Tunggal as the ruler of the universe in the theology of Sunda Wiwitan, and they call it Allah or Adam Tunggal as His successor. The term Adam Tunggal or Adam and Eve cannot be found in the literature or Sunda Wiwitan, Hinduism and Buddhism. These terms are typical of Islam and other Abrahamic religions, so using them among the Sunda Wiwitan community of the Baduy is proof of their absorption of Islamic faiths (Misno, 2014).

Another influence of Islam on Sunda Wiwitan is reading the Shahada of Muhammad as the Messenger of Allah during marriage. The reading of the shahada is done before the penghulu (village priest) who is located in Cicakal Girang village (interview with Armani the penghulu of Cicakal Girang. At present, there are other penghulu in Cicakal Girang and several penghulu in the area of the Ciboleger and Baduy Kompol and carry out the recording of the marriages of the Baduy people and teach them to read the shahada (interview with Muhammad Kasja, a resident of Muslim Baduy in Baduy Kompol). In addition to reading the shahada, the pantun (rhymes) which exist among them have also been penetrated by Islamic terms such as Allah, Muhammad, Adam and others. Furthermore, the spells read by the puun contain a lot of Islamic terms (Pleyte, 2006).

In this light, in fact, we can see the attitude of the important figures in Sunda Wiwitan who are open to the beliefs that come from the outside, although of course not on the things that are the principle. But this is one of the keys to their survival, namely by means of blending with the belief of society in general. This strategy is very effective to defuse a confrontation between Sunda Wiwitan and other religions (notably Islam). If Sunda Wiwitan refuses to blend with its surroundings, then it could be destroyed and abandoned by his followers, although this prediction still requires verification in the days to come.

The influence of globalization has also entered into the protected land of Baduy and undermined the belief of Sunda Wiwitan. If in the past they rejected unequivocally all cultures from outside, and in fact, they rejected any aid directed at them. However, currently most of their community members especially the Baduy Luar have undergone changes in almost every aspects of their life. The use of modern tools has been considered common, where they already have radios, Tape Recorders, TVs and cell phones. They now also wear colorful clothes, and they have got used to such clothing. In the past they were strictly forbidden to learn to read and write, but now some of them have learned and become literate even though they do not attend formal schools (observation and interviews with Jasid, a resident of Cipaler Village, Baduy 
Luar).

With regard to certain belief some of the things, that were originally considered forbidden, have now been ignored. Belief in good and bad days has long gone. In addition, belief in dwellers of scary places has started to be abandoned. Even belief in the existence of Batara Tunggal as the only ruler of the universe and all his obligations should be implemented has already started to be abandoned. Adherence to the puun especially among the Baduy Luar community has also diminished. One of the facts is in the celebration of the Seba has experienced a change, in which once it was religious obligation but now it has turned into travel to the city (Richard, 2010).

Sunda Wiwitan currently is at a crossroads, whether it would still be consistent with tradition or slowly be abandoned. The changes that occur to Sunda Wiwitan are not only due to the influence of other religions, but also because the Baduy community members are increasingly "advanced" so that they are slowly abandoning restrictions. The theory on the great tradition and little tradition to a certain extent is compatible with the circumstances of Sunda Wiwitan. Currently, the belief of Sunda Wiwitan has experienced a reduction with other beliefs especially Islam. Historically, it was in fact only a local belief in the existence of the power of the Almighty on Earth. Its rituals are so simple that when there are other religions that are more complete, this belief will easily adopt them (Garna, 2013).

Sunda Wiwitan has been through a long journey that has formed its current shape. Interactions with various major religions of the world have made it rich with new nuances though remains consistent with its origins. Referring to the theory of the existence of religion, then we can say that it is still in existence and is able to align itself with the changing times. Otherwise, it will be abandoned by its followers. Sunda Wiwitan has effective strategies to keep their belief alive and be observed by the community members. The choice to blend is a strategy to keep and maintain its existence as a local belief. The future of Sunda Wiwitan is in the hands of its believers; if they remain consistent and are able to adapt to the limits allowed by the pikukuh karuhun, then it will remain alive, not merely in the legend.

\section{CLOSING REMARKS}

Sunda Wiwitan is a local belief that to this day is still observed by the community of Baduy in the Kanekes Village, Lewidamar Sub-district, Lebak District, Banten Province. This belief has been around since the formation of this community especially during the Sunda Kingdom (Pajajaran). It can 
be traced back to the time of the Kingdom of Tarumanegara and the early megalithic age. The historical fact of the belief in Batara Tunggal or Nu Kawasa is evidenced by the kabuyutan relics that now become a sacred place for this belief. One of the well preserved sacred places is Sasaka Buana or Arca Domas in Baduy.

Sunda Wiwitan is based on belief in Batara Tunggal or Nu Kawasa as God Almighty. In addition, they also believe in the existence of gods which is the influence of Hinduism such as the Goddess Sri or Nyi Pohaci. The belief which is the ancestral heritage is the belief in the Guriang as the spirit of its ancestors and Wangatua as the spirit of the deceased parents who look after their offsprings. Islam has significant influence on the belief of Sunda Wiwitan. The belief that Allah is the creator to replace the term Batara Tungal, the existence Adam Tunggal, Adam and Eve, recognition of the Islamic prophet Muhammad and Shahada of Muhammad give evidence that they absorb the Islamic beliefs. The Pantun and spells which are read by the puunr and important figures of Sunda Wiwitan puun have been influenced by Islamic terms.

All these facts indicate that Sunda Wiwitan is absorbent enough to belief outside of it, especially on things that are not the principles and subject matter. Its method of adoption of elements from other religions is a strategy for this belief to exist and be able to follow the development of the times.

\section{BIBLIOGRAPHY}

A, Suhandi Sam, 1996. Tata Kehidupan Masyarakat Baduy Daerah Jawa Barat, Bandung: Departemen Pendidikan dan Kebudayaan.

C.M. Pleyte. 2006. Arca Domas: Tanah Persemayaman Roh Orang Baduy, terj. Judistira K. Garna. Bandung: Primaco Akademika dan Judistira Garna Foundation.

Danasasmita, Saleh dan Anis Djatisunda. 1984. Kehidupan Masyarakat Kanekes. Jakarta: Departemen Pendidikan dan Kebudayaan Direktorat Jenderal Kebudayaan Proyek Penelitian dan Pengkajian Kebudayaan Nusantara (Javanologi).

Danasasmita, Saleh. 2012, Nyukcruk sajarah Pakuan Pajajaran jeung Prabu Siliwangi. Bandung: Kiblat Buku Utama.

Dhavamony, Mariasusai. 1995. Fenomenologi Agama (terj.). Yogyakarta: Kanisius.

Djoewisno, MS. Potret Kehidupan Masyarakat Baduy. 1987. Banten: Cipta Pratama Adv.pt.

Ekadjati, Edi S. 2009. Kebudayaan Sunda: Suatu Pendekatan Sejarah Jilid I. Jakarta: Pustaka Jaya. 
Garna, Judistira K. 1987. Orang Baduy. Bangi: Universiti Kebangsaan Malaysia.

Garna, Judistira K. 1988. "Perubahan Sosial Budaya Baduy", dalam Nurhadi Rangkuti (peny.). Orang Baduy dari Inti Jagat. Yogyakarta: Bentara Budaya, Kompas, Etnodata Prosindo, Yayasan Budhi Dharma Praseda.

Garna, Judistira K. 1993. "Masyarakat Baduy di Banten”, dalam Koetjaraningrat (ed.), Masyarakat Terasing di Indonesia. Jakarta: Departemen Sosial RI, Dewan Nasional Indonesia untuk Kesejahteraan Sosial dan Gramedia.

Garna, Judistira K. 1993. “Orang Baduy di Jawa: Sebuah Studi Kasus mengenai Adaptasi Suku Asli terhadap Pembangunan", dalam Lim Teck Ghee dan Alberto G. Gomes (peny.), Suku Asli dan Pembangunan di Asia Tenggara. Jakarta: Yayasan Obor Indonesia, hlm. 142-160.

Geertz, Clifford. 1973. The Interpretation of Cultures, Selected Essays. London: Hutchinson \& Co (publishers) Ltd.

Hakiki, Kiki Muhammad, 2010. Makna Tradisi Seba pada Komunitas Baduy, Bandung: Universitas Islam Negeri Sunan Gunung Djati.

Iskandar, Johan dan Budiawati S. Iskandar. 2011. Agroekosistem Orang Sunda. Bandung: PT. Kiblat Buku Utama.

Jacobs, Julius. 2012, De Badoej's, terj. Judistira K. Garna, Orang Baduy dari Banten. Bandung: Primaco Akademika dan Judistira Garna Foundation.

Kartawinata, Ade Makmur. 1993. Baduy Bubuara Menatap Tanah Harapan. Pusat Penelitian Kemasyarakatan dan Kebudayaan Lembaga Penelitian Universitas Padjadjaran

Koentjaraningrat, dkk. 1993. Masyarakat Terasing di Indonesia. Jakarta: Gramedia Pustaka Utama.

Kurnia, Asep dan Ahmad Syihabudin. 2010. Saatnya Badui Bicara. Jakarta: Bumi Aksara dan Universitas Sultan Ageng Tirtayasa.

Miles, Matthew B. dan A. Micheal Huberman. 1992. Analisis Data Kualitatif (terj.). Jakarta: Penerbit Universitas Indonesia.

Misno, Abdurrahman. 2014. Penyerapan Hukum Islam oleh Komunitas Adat Baduy, Kampung Naga dan Marunda, Disertasi. Bandung: Universitas Islam Sunan gunung Djati.

Permana, R. Cecep Eka. 2005. Kesetaraan Gender dalam Adat Inti Jagat Baduy. Jakarta: Wedatama Widya Sastra.

Permana, R. Cecep Eka. 2006. Tata Ruang Masyarakat Baduy. Jakarta: Wedatama Widya Sastra.

Permana, R. Cecep Eka. 2010. Kearifan Lokal Masyarakat Baduy dalam Mitigasi Bencana. Jakarta: Wedatama Widya Sastra. 
Rahardjo, Djoko Mudji dan Yuke Sri Rahayu. 2002. Urang Kanekes di Banten Kidul, Jakarta: Proyek Pemanfaat Kebudayaan Direktorat Tradisi dan Kepercayaan Deputi Bidang Pelestarian dan Pengembangan Kebudayaan dan Pariwisata.

Spradley, James P. 2006. Metode Etnografi (terj.). Edisi Kedua. Yogyakarta: Tiara Wacana.

Suhendar, Haris. 1985. Peninggalan Tradisi Megalitik di Daerah Cianjur Jawa Barat, Proyek Penelitian Purbakala Jakarta.

Suryani NS, Elis. 2008. Merumat Warisan Karuhun Orang Sunda yang terpendam dalam Naskah dan Prasasti. Bandung: Alqa Print. 
